\title{
Would Teaching Sustainable Development Business Strategies Shift Students' Mindsets? An Australian Experience
}

\author{
Theodora Issa, Curtin University, WA, Australia \\ Tomayess Issa, Curtin University, WA, Australia \\ Vanessa Chang, Curtin University, WA, Australia
}

\begin{abstract}
The aim of this study is to examine students' Reactions towards sustainability and 'Green IT' following the completion of the postgraduate unit ITS6 in semester 2 2010. It is evident that emerging concept relating to the topic 'Sustainability and Green IT' are gaining momentum, having an increased importance for both practitioners and academics alike. This comes especially following the self-reflection by all parties following the Global Financial Crisis of 2008/2009 coupled with the ongoing change in climate. Both of these factors are having their negative ramifications on individuals, businesses, communities, and societies, urging them to question their involvement and any efforts that they might exert to avert or rather reduce the negative consequences experienced so far. Business schools were amongst those who have been blamed for economic, societal and environmental failures. Several of these business schools were and continue to be taking measures to rectify what might have been lack of concentration on 'soft issues' in business and management. Indeed, the idea behind the development of ITS6 unit was to enhance and improve students' awareness of the roles information technology and information systems play in business, their impact, and that of business on all aspects of life including the environment. To assist students to achieve this unit's outcomes, assessments were designed in a manner that would allow them to foster synthesis within their studies, thus developing, improving, and enhancing their learning and understanding. The assessments were three: three reflective accounts/journals, an oral presentation, and a written report. Through the preparation of their three reflective accounts/journals, students were able to reflect on their learning. This activity formed a major part of their overall unit assessment. This specific activity and being in three parts allowed proper monitoring of students' developments and enhanced capabilities. This assessment was designed to offer students the experience to critically, creatively and reflectively, review and record key aspects and concepts. These experiences were coupled with their thoughts about materials provided or located by them either through their ongoing readings of textbooks, journal articles or through their searches over the World Wide Web. Adopting this assessment at the postgraduate level while teaching 'ITS6' entailed two benefits. First, it allowed us to teach students how to analyse and synthesise the diverse types of information outlined in the sourced articles and publications. Second, as a result of their own readings, analyses, and syntheses, students were able to enhance their own learning in this unit, thus displaying a shift in their frames and understanding of the material presented to them and generated by them. As a result, this unit ultimately changed the students' mindsets. For this study, the researchers collected the data through quantitative and qualitative techniques. This was done to lessen the shortcomings of each method when used on its own. This study provides a reflection on such activity, establishing a comparison to ascertain whether students have benefited from the material provided in this unit, and thus whether outcomes identified and attached to this unit were achieved. This study is a rather modest contribution to the ongoing debate as to whether students' mindsets shift following exposure to material that they were almost unaware of, thus changing their mindsets and transforming them into advocates of sustainable development and its relationship with the IT industry.
\end{abstract}

The International Journal of Environmental, Cultural, Economic and Social Sustainability Volume 7, Issue 5, 2011, http://www.Sustainability-Journal.com, ISSN 1832-2077 (c) Common Ground, Theodora Issa, Tomayess Issa, Vanessa Chang, All Rights Reserved, Permissions: cg-support@commongroundpublishing.com 
Keywords: Sustainability, Business Strategies, 'Green IT', Mindsets, Postgraduate Students, Australia

\section{Introduction}

I

N ESTABLISHING THE case for sustainability and its relationship to business, Epstein and Roy (2001) provide businesses with a framework through which they organize the drivers of corporate sustainability and financial performance into five major components.

These five components are: (1) Corporate and business unit strategy, (2) Sustainability actions, (3) Sustainability performance, (4) Stakeholder reactions, and, (5) Corporate financial performance. As organizations address the importance of sustainability, universities are obliged to also focus on the same issue. With Epstein and Roy (2001) or similar framework, business schools are also looking at the importance of sustainability and raises the need to incorporate such a topic in their degrees.

One of the units (courses) that form a part of the postgraduate studies is the subject of this study. This paper aims to provide a brief literature review, moving to the provision of evidence that is derived from students' own submissions and reflective comments on the change and the shift in their mindsets. A shift in the students' mindsets albeit on different levels was noticed. These levels ranged from total ignorance by some to having some knowledge about such issues. However, all students had a mindset shift, moving into appreciating highly of the value of sustainability and its importance for a more appropriate strategy that takes into account the long-term health of the corporation.

For the same reason and due to the growing global impact of both Information Systems (IS) and Information Technology (IT) on global economy, ecology and society; businesses, both globally and locally, have extended their business strategies to include sustainability. In the field of IS and IT, 'Green IT' seems to gain favour with business strategists forming a major part of their Information Systems Management strategy (Weybrecht 2010). Sustainability and 'Green IT' are essential in the Information Systems Management strategy. Its importance is highlighted by the fact that the present generation does not own the planet and its resources, but is allowed to use and hold it in trust on behalf of future generations. In this respect, sustainable development meets the needs of the present generation without compromising the needs of the future generations. Therefore, strategies designed and implemented should be able to accommodate this goal and aim. For example, research indicates that adopting this strategy offers various benefits in electric power reduction consumption of IT hardware and reduction in $\mathrm{CO}^{2}$ emissions. Furthermore, it was indicated by Erek et al. (2009, p.1) that 'Google, for instance, operates about 450,000 servers consuming nearly 800 million $\mathrm{kWh}$ a year'.

European Greens (n.d.) suggest that green economic vision puts social and environmental justice and equity within nations and between nations at the centre, a just use of the earth's resources (e.g. reducing the gap between rich and poor). Every person has the right to acquire and receive their basic needs, such as clean air, water, food, soil, shelter, energy, health, and freedom. Every human being has a right to solidarity, democracy, self determination, autonomy, responsibility, dignity, self-fulfilment and the economy should enhance wellbeing and not detract from it. Furthermore, the European Greens (n.d.) argue that the green economy should play a central role for investments in sustainable development and green technology, and should create new opportunities, in particular on the labour market, making it possible for everyone to exploit his or her talents. Therefore, the key to greening the economy is to 
make it less intensive in its use of natural resources, but the most essential is to have the proper incentives starting with appropriate leadership. This study will show how the assessments, especially the writing of journals in 'ITS6' postgraduate unit (course), had played a role in attempting to shift the students' mindsets, making them become more aware with respect to sustainability and IT development strategy. The most important aspect was the concluding remarks by students following their attendance and completion of these journals. It was noted that students' feedback indicated that organizations and firms should integrate sustainable strategy to allow them to be more competitive in the marketplace locally and globally.

\section{Background and Literature Review}

\section{What is Sustainability?}

In 1983, the sustainability concept was founded and addressed by Gro Harlem Brundtland, from the World Commission on Environment and Development meetings. In 1987, the Gro Harlem Brundtland's report was released to alert the global world to the urgency of making progress towards economic development. With this, there is a requirement that human beings use the world in a way that will not endanger the future generations. Newton (2003) indicated that, the seventh generation should have the ability to derive the same benefits from similar activities. Weybrecht (2010, p.14) indicated that sustainability can be defined for the business sector as 'adopting business strategies and activities that meet the needs of the enterprise and its stakeholders today while protecting sustaining and enhancing the human and natural resources that will be needed in the future'. Therefore, it is necessary to request organizations and firms to protect the environment not only for the service of the current generation but to safe-keep this environment for at least the seventh generation allowing them the chance to enjoy at least the same level of resources as this generation. Kuhlman and Farrington (2010, p.3439) while casting some doubt on the value of the concept of 'sustainability' as it was intended by the Brundtland Commission (1983) stating, 'If 'sustainability' is anything more than a slogan or expression of emotion, it must amount to an injunction to preserve productive capacity for the indefinite future'. Consequently, sustainability as a term has become very popular and most organizations and firms apply it or are in the process of developing their strategies to incorporate it, especially following empirical evidence outlining benefits, even long-term financial benefits, for implementing and incorporating sustainability in the overall business strategies (Epstein \& Roy 2003).

\section{What does Sustainability mean for Business?}

Sustainability and 'Green IT' are concepts that are gaining momentum in organizations and firms locally and globally. This might not have been a voluntary act on behalf of these organizations and firms, but rather the majority of these organizations and firms have been under growing pressure to implement and address these concepts in their companies either by their stakeholders or through legislations. According to Newton (2003) it was noted that incorporating sustainable strategy with emerging technologies has become the norm in contemporary businesses, an idea that has its support from Erek et al.(2009, p.2) who contend that 'sustainability has been extensively discussed within corporate management under the 
synonyms of corporate social responsibility (CSR), greening the business eco-efficiency or eco-advantage'.

Newton (2003) indicated that there is a relationship between sustainability and the idea of stewardship. Organizations and firms should ensure that they have the value commitments to sustainability to act competitively in the marketplace. Newton (2003) identifies values that must be considered to assist businesses in achieving this competitive advantage through paying attention to the idea of sustainability and stewardship. These values are: (1) personal integrity, which indicates that all people must develop a single, comprehensive and internally coherent worldview that is good and that people strive to act out in their daily lives, (2) wisdom, which includes sensitivity to natural processes, (3) courage, which includes and entails patience, (4) temperance, that highlights frugality, (5) justice that brings forth respect for that which is other than ourselves, (6) love or fidelity that highlights compassion, (7) community, (8) simplicity, (9) humility, furthermore, most importantly above all (10) responsibility and accountability. These values would assist businesses disposition to carry out effectively stewardship of which, this has been placed in their care. It might not be easy to incorporate all these values in the way organizations think and deal with the issue of strategy, but practice would be the key and implementation can be achieved over a period of time. Nonetheless, organizations are urged to take the first step in implementing these values.

Newman (2003) contends that only virtue ethics will permit any worthwhile environmental ethics. Fidelity and community are central virtues, alongside traditional wisdom, courage, temperance, and justice. Newton (2003) warns that individuals who would live a caring life in community live in contradiction if they live in violation of environmental sustainability.

Weybrecht (2010) and Smith and Sharicz (2011) argue that organizations and firms that are successful are building their strategies with sustainability to meet and suit the whole business not limited to the management level. Therefore, incorporating sustainability in businesses' operations can provide organizations and firms with various benefits (e.g. cost reduction; resources preservation; conforming legislation, improvement of reputation, maintaining happier customers and stakeholders, attracting capital investment and capitalizing on new opportunities, just to name a few). Businesses should support sustainability adoption as soon as possible, as Wexler $(2009$, p.70) posited that 'arguing for change as represented by the emergent coalition rather than going it alone or staying with the status quo'.

Finally, the journey towards more sustainable strategies is very important and essential; therefore, organizations and firms should understand where they are now and where they want to be in the future. There is a need for them to understand their goals and objectives before heading for the design and implementation of a sustainability strategy. Indeed, according to Kendall \& Kendall (2010) sustainability will benefit not only the company's shareholders but will extend to include the society.

\section{Sustainability, Green IT and Education}

Following the Global Financial Crisis in 2008/2009, businesses started to struggle to cope with the increased in IT/IS costs and their environmental footprint. Arevalo (2010) urges for paying more attention to the issue of sustainability and global social responsibility in business as a whole. Arevalo (2010), providing empirical evidence, argues that relationships between environmental and economic dimensions of sustainability have been solidly specified, 
yet argues that relatively little attention has been given to the social sphere. Arevalo (2010) concludes that there is a transformative effect on citizenship that can result from the training that is facilitated by voluntary corporate social responsibility initiatives. These initiatives can only become serious and acted upon if they are incorporated within and become an integral part of the company's strategy.

Uhlman 2008 (cited in Jenkin, Webster \& McShane 2010, p.2) indicated that IT/IS products have short product life spans (e.g., laptops with 3-4 years; networks with 5-7 years). The manufacturing, followed by heavy consumption and disposal have resulted in toxic hotspots. In addition, it is a known fact that a large portion of organizations' electricity costs (and concomitant greenhouse gas emissions) is due to IT energy use (e.g., office buildings with $26 \%$; data centres with $95 \%$ (Siegler \& Gaughan 2008)). Therefore, businesses seem to have started moving and quickly towards adopting a sustainable strategy, this is coupled with actions by universities to incorporate sustainability and 'Green IT' as parts of their teaching and learning materials, acknowledging their importance for businesses. This interest by businesses and universities has come in the form of introducing some new concepts. For example, 'Green IT', is a concept that brought with it the 'ecological impact of IT into the public and academic focus' (Schmidt et al. 2009, p.400). Marques (2009) reviews an important paradigm shift that is currently spreading amongst humanity, instigating a critical analysis of the way matters in past centuries were perceived, and encouraging an entirely opposite way of approaching the essentials of contemporary life. To clarify this perceptional change, Marques (2009) discusses different areas such as education, and economics amongst others. In this respect, Walck (2009) confirms that majority of academics, globally and locally, are shifting towards 'green' and 'sustainable' ways of thinking in management and Information Systems curriculums, just to name a few.

However, it is important that these units (courses) must be mapped properly, ensuring the proper flow of the material provided, and proper linkage between assessments, and the unit (course) outcomes. Developers of such units (courses) should always pose the questions, as to what outcomes might be desirable, and what assessments should be included to meet students, university and marketplace requirements simultaneously. This has increased in its importance especially with the latest developments in the market, and environment that poses great challenges to the humankind. To meet these increased challenges, a postgraduate unit (course) ITS6 was designed to examine the strategic development issues that need to be taken into account to allow the future IT business leaders act responsibly towards achieving their goals as stewards of the planet, people, and their profit.

The aims of ITS6 unit (course) were to: (1) provide students with some understanding of issues relevant to Organizational Sustainable Strategy, (2) provide students with some understanding of issues relevant to 'Green IT', and, (3) establish the link between the two areas. As for the learning outcomes of ITS6 unit (course), those were: (1) students to demonstrate initial awareness and sensitivity to the importance of sustainable development and business strategies in such a crucial time for people and planet and ultimately profit, and, (2) students to display proper abilities to translate theories, concepts, and analytical techniques learnt into practice.

To examine the achievements of these aims and outcomes, assessments were designed taking into account the different ethical perspective different individuals might have in relation to sustainability. These assessments were all required to be submitted on individual basis. This was coupled by some group work. While the individual assignments were assessed to 
generate the final mark for the students in this unit (course), the group work was merely left for class activities, which included discussions, case studies and debates rather than group assignments. The individual assessments were: (1) three reflective accounts/journals, (2) individual Presentation of an IT Sustainable Strategy proposal, and, (3) report writing of the IT Sustainable Strategy that students proposed in their second assignment using the frameworks and tools provided. An important feature was stressed upon in this assignment, the fact that students would locate frameworks and models (other than those explained in the unit (course) through their ongoing research throughout the semester, which they used in their individual assignment.

The three-part reflective accounts/journals were designed to provide student(s) with valuable experience in critically, creatively and reflectively, reviewing and recording key points and their thoughts about material from textbook(s), journal articles and the World Wide Web. In addition, this assessment encouraged student(s) to keep themselves up-to-date with their readings and their ongoing search in the World Wide Web in relation to the topics under study. It is worthwhile to note here that the reflective accounts/journals were not meant to only form a summary of the readings but student(s) were encouraged to provide their own opinions, and reactions to the material provided in these sources, reflecting on the contents and providing additional evidences from the literature they sought.

The second assessment was in the form of oral presentation. This individual oral presentation was designed to promote student presentation skills and their arguments abilities as they were faced with questions from the audience (classmates and unit (course) lecturers) that would usually form part of such presentations. Students' presentations provided a brief, concise, and succinct account of their major IT sustainable development strategy for a company of their choice. The method adopted in running those presentations also enhanced the learning of those students. Thus, and in order to achieve this aim, and maintain interest, students were provided with marking guides to assess their peers' performance, to the extent of allocating marks. These marks were taken into account when evaluating the overall mark of each of the students. The fact that students were allowed to assess their peers was taken seriously by students, who were also generous with their remarks on what went well, wrong, and who could have done better.

The third individual assignment aimed at providing students with the ability to write professionally and academically. The proper way to achieve such aims, communicating with their lecturers was through writing a report enhancing their analysis of the company's present strategy, their recommendation using different frameworks, tools, and models. In some cases, students were courageous enough to even suggest the deletion of stages in some of the models, and addition of stage to other models that they derived from scholarly work in this area. All this was derived from solid research and understanding. In this study, only the first assignment of these course assessments (i.e. reflective accounts/journals by students) will be explored.

\section{Reflective Accounts/Journals}

Reflective accounts/journals are not new to education, including higher education. As outlined by Baron (1981), Dewey (1933) proposed that 'reflective thinking' ought to be encouraged by education. It is noted that reflective accounts/journals have been used widely in the education programs especially in Higher Education to promote critical thinking (Clarke 2003). 
These reflective accounts/journals are designed to promote several skills for students including critical and reflective thinking, writing, and research skills. Reflective accounts/journals are considered amongst the special practice assessments methods. This method allows students to learn the concepts under examination by themselves. Titus \& Gremler (2010, p.184) identify 'reflection journals' as a type of 'self-research', designed to provide greater awareness of a person's own instructional beliefs and practices'. However, Hubbs \& Brand (2010, p.60) argue that applying reflective accounts/journals in higher education assessments, 'can challenge students' prior patterns of thinking and can result in transformative learning'.

Baron (1981) proposed a general normative (perspective) model of the phases of reflective thinking problem recognition, enumeration of possibilities, reasoning, revision, and evaluation. In this unit (course), students were exposed to problems, allowing them, and through the display of images and video clips to realize the dangers of continuing to adhere to the same principles that had brought pollution to the plant's atmosphere that is ultimately damaging not only the plant's health, but also humankind's. Contemplating the students' direct reactions to such confronting images, students were quizzed as to what changes they might recommend or anticipate might be required to reduce the dangers posed. Through intelligent discussions, students were able to recognise that they have a responsibility, displaying an understanding of their role, a task that has proven to be very difficult at the start. However, later on, and through further readings, and discussions, students came to understand the responsibilities bestowed on them as the IT/IS professionals towards the improvement of the plant's health and ultimately the humankind's health. Applying reasoning, revision, and evaluation of the current situation, frameworks and tools, students came to understand what needs to be done and how the application of such frameworks and tools might reduce the impact of this industry on the community, society and the environment as a whole.

Incorporating reflective accounts/journals as part of postgraduate unit (course) assessments has several benefits. One of these benefits would be enhancing their ability to think critically, which in turn would assist them to enhance their academic writing. Students were able to achieve this through being provided with the proper resources and materials, and encouraging them to enhance their abilities to conduct research in such areas.

\section{Method}

\section{Research Question and Objective}

This study will answer the question: 'Would the teaching of sustainable development business strategies allow a shift in students' mindsets?' Gunn \& Gullickson (2005) explain that mindsets shape word and action, direction and deed; with repetition, neurons in the brains connect ever more strongly, and channels of consciousness are dug deeper. However, they conclude that mindsets must change in response to changing ways of thinking, thus allowing for a state of mind that enables individuals to act and lead in a dynamic world. Thus, this study mainly aims to report on an examination if teaching about environmental sustainability and 'Green IT' for postgraduate students in Australia will generate a shift in students' mindsets through analysis of the first assignment of three-part accounts/journals done by postgraduate students who undertook the ITS6 unit (course) in 2010 in Australia. In examining the three-part reflective accounts/journals presented by students, assurance can be established if the outcomes have been achieved, and whether students' mindsets would shift (or have 
shifted) following their exposure to material that some of whom were almost unaware off. In addition, would this shift transform those students into becoming advocates of the importance of environmental sustainable development at all levels, and most importantly its relationship with IT industry of such a strategy.

\section{Methodology}

Reinhard (2005) contends that individuals' beliefs are formed either in themselves, in nature or in any other issues that are surrounding them. It is somewhat difficult to change these beliefs, and this difficulty increases with age, education and experience individuals are exposed to. These ideas can be challenged, and the challenge can only be based on the submission of empirical evidence. The best method to collect empirical evidence would be through the application of a mixed-method approach. Walker (1997) and Green (2008) are of the opinion that each of the techniques (i.e. quantitative or qualitative) if used solely has its shortfalls, and in combining, both the shortcomings of each will be reduced. Another study was conducted by Gilbert (2006) indicate that combining qualitative and quantitative approaches in research will reduce the gap between the finding and their strengths will 'provide insights, analysis integrates these insights into a single narrative' (Gilbert 2006, p. 208). It was noted that mixed-method design provides various benefits to the research mainly: 'good communication between stakeholders; confront researchers' methodological and methods assumptions, suspend immediate judgments; embrace researchers' differences. In addition, a practice reflexivity by listening across researchers' differences as a means toward building a new set of shared assumptions, and if not, at least a willingness to remain open to different points of view' (Hesse-Biber 2010, p.417-418).

In this study, data was collected through the quantitative and qualitative techniques, from lecturers' records and students' feedback. The students' feedback was collected twice during the semester. The first was through the informal feedback while students were still studying. The second was following the end of the semester, which is the University's formal feedback (eVALUate). This 'eVALUate' is applied at University at the end of each semester, when students voluntarily and anonymously provide their feedback on the unit (course) and the teaching staff. The 'informal feedback' is a teaching and learning initiative, when during the semester, students were asked to provide their anonymous feedback on the unit (course) using the model 'Continue, Stop, Start' (CSS). By completing the CSS students were given the chance to express their opinion, providing their comments of what they need continued, stopped or started by the lecturer. This action provided the lecturers and the students with the chance to reflect and think about the benefits of the course, which assists in enhancing the students' teaching and learning.

Following the analysis of the collected data (informal and formal feedback), it was noted that students were so keen to study the material provided in ITS6 unit (course), which enhanced their knowledge, challenged their beliefs. Their exposure to such material had encouraged them to seek more articles and material to support the ideas that have been planted through the first session of this unit (course). What became apparent that students came to enhance their abilities, including their critical thinking, writing and reading skills. Some of the students' comments (informal and formal feedback) will be elaborated upon in the discussion section of this study. 


\section{Participants}

The ITS6 participants were a mix of students from different backgrounds. Some were with work experience, while others were students who have elevated through their undergraduate studies at the university without any exposure to any type of work including in the field of IT/IS. This was a challenge that the lecturers had to deal with, through the scaffolding offered to those who were finding it difficult to think of the practicality of the issues under discussion. Another challenge was the students' different backgrounds. Some had completed their undergraduate studies moving into post-graduate studies at the same university, while others had only joined our university merely to acquire their postgraduate studies bringing with them diverse ideas and real-life experiences relevant to culture.

Table 1: Demographic Details of ITS6 Students

\begin{tabular}{|l|c|c|c|c|c|}
\hline Qualification & Number & Gender & Nationality & $\begin{array}{c}\text { Work } \\
\text { Experience }\end{array}$ & $\begin{array}{c}\text { Final } \\
\text { Unit } \\
\text { (Course) }\end{array}$ \\
\hline Master of Commerce (IS) & 2 & None & Asia, Mauritius & $\begin{array}{c}1 \text { Middle, } 1 \\
\text { Low }\end{array}$ & Nil \\
\hline $\begin{array}{l}\text { Master of Information } \\
\text { Systems }\end{array}$ & 8 & 1 Female & $\begin{array}{c}6 \text { Asia, 2 } \\
\text { Middle East }\end{array}$ & $\begin{array}{c}1 \text { Middle, } 7 \\
\text { Low }\end{array}$ & 5 \\
\hline Honours & 1 & None & Asia & 1 Middle, & Nil \\
\hline $\begin{array}{l}\text { Postgraduate Diploma of } \\
\text { Commerce (IS) }\end{array}$ & 6 & 1 Female & $\begin{array}{c}5 \text { Asia, 1 South } \\
\text { Africa }\end{array}$ & $\begin{array}{c}1 \text { High, } 5 \\
\text { Low }\end{array}$ & 2 \\
\hline Master of Logistics & 1 & None & India & 1 High & 1 \\
\hline Total & 18 & & & & \\
\hline
\end{tabular}

\section{Discussion - Shifting Students Mindsets}

For this ITS6 unit (course) the employment of the three-part reflective accounts/journals as one of the assessment methods was considered an effective way to engage students in the learning activities, thus enhancing their understanding of concepts that in some cases were considered 'unknown' to them, such as sustainability and 'Green IT'. The three-part accounts/journals were worth $30 \%$, divided in three equal parts. Each account/journal focused on specific articles to instigate students' abilities to understand the relationship between sustainable business development and 'Green IT' allowing them the chance to 'think holistically rather than conventionally' (Pavolvich, Collins \& Jones 2009, p.38). Students were provided with the proper format 'template' to allow them present an academic piece of work, when completing this part of assessments. The template (developed by the Skills and Communications Centre at the School) was of six sections: (1) full bibliographical references, (2) what is the subject/theme of this article, (3) what is the argument made by the author, (4) how do this author's views compare with what others have said on the same or similar topics, (5) what are your own thoughts on the subjects, and, (6) conclusion. Whilst the first three sections were merely deriving from the articles provided, sections 4,5 and 6 were de- 
signed to allow the students the chance to critically analyse, and synthesise their readings of similar articles and research material. Going through the fifth and sixth sections of this reflective account/journal, it was evident that students have exerted efforts and came to understand topics, reflecting on articles at hand, bringing in some sources in support or even in contradiction with the thoughts included in the articles provided.

Thus, through monitoring the development of the students' critical and analytical abilities by marking the three-part reflective accounts/journals it became evident that such activity has allowed to a shift in the mindsets of students through the application of analytical and critical skills. This echoes Cunliffe's (2004, p.408) argument, who posit that using this method in business education can develop 'collaborative, responsible and ethical ways of managing organisations', 'and not thinking about thinking, but thinking about self from a subjective process' (Cunliffe 2004, p.418). This was evident in some of the comments provided by the students in their either reflection or conclusion in the accounts/journals under discussion. From these comments:

'The learning experience helps me to improve communication skill and start to think more critically'. (Student 1)

'This unit (course) helps us to improve the research skills by reading many articles concerning on the environmental, social, political and technological issues. As we have done some case studies in seminars, and it could be a good practice for analysing the enterprises and strategic thinking process'. (Student 2)

'I felt my learning has been improved since the beginning until the end. Very good introduction of the unit (course) and I hope more students will take this unit (course) for a valuable opportunity to see things in a different way'. (Student 3)

This is important especially with ongoing societal transformation, uncertainty, and risk, individuals are more than ever dependent on each other to survive and thrive (Gini \& Marcoux, 2009). Thus, the more aware they are of the consequences of their actions on others, society and environment, the more careful these individuals will be in taking decision and acting in their positions.

As highlighted earlier, the majority of articles that were provided to students in this unit (course) had a focus on sustainability and 'Green IT'. The main idea was to assist them to gain necessary knowledge and develop their skills to establish a comprehensive understanding of these concepts. Majority of students indicated that the ITS6 was an interesting and challenging unit (course). From students' comments:

'Our brain has been washed to green'. (Student 4)

'[Our] mind has been changed from original [stand]'. (Student 5)

'I have clearly realized that what is sustainability and what are motivation of people and business to do that and more important is that I have understand most current design in IT has aimed to be sustainability... That is very important to me Thank YOU'. (Student 6)

'This unit (course) has started my migration from technical to management focus and for this I am appreciative'. (Student 7)

Going through the students reflections, more evidence can be derived. For example 
'Improve [our] reading skills, analysing and reflecting from journal readings'. (Student 8)

Still going through the reflections, one of the students felt that the most important aspect behind this unit (course) was:

'Up-to-date information and self learning attitude'. (Student 9)

'As these concepts are about current business environment they can be used in reality'.

(Student 10)

'Changing the way of thinking from individual to more social'. (Student 11)

After introducing the ITS6 unit (course) to the postgraduate students and asking them to read and search for articles, which are related to sustainability and 'Green IT'. Following the reading and analysis of the articles, a shift in the students' mindsets became evident, thus establishing higher awareness of how organizations and firms should integrate sustainability into their strategy, thus forming a major part of their core business strategy and practices. The change did not stop there, but rather it was very interesting to read in their reflective accounts/journals that they feel the importance of the topics covered in this unit (course) calling for a change into the way businesses are conducted. From the students' reflections this quotation:

'More organizations should shift to sustainable IT services; the faster organizations will build long term benefits for a greener planet'. (Student 12)

'From my perspective, the good thing about green computing is this concept is well understood by most people in different area of disciplines and some are not required a deeper understanding of IT terminologies except virtualization, data centre infrastructure, or power cabling. Many people still have the mindset that being sustainable will cost money. This is true in several cases, however we have to change their way of thinking, because in the long term the saving made from operational cost could outweigh the initial cost. Businesses can save costs by improving the environment which latter deliver a positive influence financially. Going green also can boost the company's position in market share. In addition, I believe that organizations should treat their employees as investments. We treat them well; they will contribute to business value by improving their productivity. Therefore, we can achieve the same performance with fewer investments'. (Student 13)

'Money is not the most important thing. We have to concern about the environment and society'. (Student 14)

'The sooner organisations shift to sustainable IT services, the faster organisations will build long term benefits for a greener planet'. (Student 15)

'I have learned that it is important to adopt green computing and sustainability IT strategies in the organization. It does not only reduce the cost, but also help the organizations to understand that this concept encompasses different elements in terms of politic, economic, and social issue'. (Student 16) 
Introducing 'Green IT' and Sustainability should not only limit to organizations, but should include the education sector that needs to contribute by providing the necessary education to the future chief executives and others in the workplace. Patenaude (2011, p.270) highlights the need for a 'proportion of academic research to become informed by real world problems as faced by communities and businesses, inter-institution spaces for the incubation and exchanges of ideas, innovations and people, as well as neutral hubs of research, teaching and expertise are needed'. Therefore, universities and educational institutions should integrate sustainability in their units (courses), not only limited to information technology, but also should include in the marketing, accounting, management, and business in general. Students, once again, confirmed that:

'.... the problems of global warming and climate change need to be included in curriculum right from very early stages of education, building up the tempo over the years'. (Student 17)

'.... everyone should look at the fundamentals and examine the level of current educational provision to prepare for future improvement in climate change' (Student 18).

'The subject on sustainability is offered in very scanty manner in universities. Concurring with the ITS6 students who stated, 'it is the subject' everyone must learn and practice in their 'life' to care for the planet and generations to come. This course will definitely impart a good amount of 'concerns' on the sustainability of mother earth by our own actions leading to be 'reasonably good humans' in the process'. (Student 19)

This is a call for academics and practitioners to engage in a dialogue on how best higher education can serve organisations in enhancing their understanding of such an important topic in such an uncertain society.

Having indicated all the above, it is worthwhile to note here that students, were somehow apprehensive towards the number of assessments, indicating that the unit (course) came with its heavy load of reading and research. These comments were minimal in comparison to those that appreciated the style and method in running this unit (course) that they felt achieved its aims and objectives.

\section{Conclusion}

This study provided empirical evidence on how teaching sustainable development business strategies assisted in shifting students' mindsets. Indeed, evidence provided indicated a shift from being novices into to becoming advocates for such crucial issues. The majority of students indicated their satisfaction with the style of the unit (course), assessments including the three-part reflective accounts/journals. It was noted that using reflective accounts/journals in ITS6 was a challenging exercise to the students, since this assessment was divided into three journals. Each journal mainly focused on specific articles that discuss the relationship between Sustainability and 'Green IT'. This assessment was designed to provide students with experience in how to critically, creatively and reflectively, review and record the main points and their thoughts about materials from textbooks, internet, and peer-reviewed journals articles.

Comments provided by students indicated that this assessment assisted them to understand the concepts behind sustainable development business strategies and the relationship between 
strategy and IT. Majority of students agreed that sustainability for business is always shifting and embryonic, thus organizations and firms should integrate it in their strategy. Thus, contradicting Freidman's 1970 (cited in Weybrecht 2010, p.21) famous argument against anything that would divert the business attention from generating profit, arguing, 'there is one and only one social responsibility of business-to use its recourses and engage in activities designed to increase its profits so long as it stays within the rules of the game'. This study contributes to reshaping the way students think with regards to the environmental sustainability and 'Green IT'. Further, based on students' feedback follow-on research will be carried out to modify the assessments (to develop more interactive ones in the class i.e. using WIKI) and enhancing the information provided in the unit (course) in relation to developed and developing countries.

The ITS6 unit (course) might act as an exemplar to provide guidelines for educational institutions to integrate sustainability in their units (courses). Several questions were raised as to what role higher education would play in improving methods adopted by businesses locally and globally to lessen their impact on the environment, and run their businesses in a more responsible, accountable and sustainable manner. Indeed, responsibility lies in the hands of academics who are forming the leaders of tomorrow and practitioners who are using the resources that are borrowed from future generations. This is not an easy task, but rather a co-operation and co-ordination between academics and practitioners to achieve this change of mindsets thus resulting in a sustainable future for all. 


\section{References}

Arevalo, JA 2010, 'Critical Reflective Organizations: An Empirical Observation of Global Active Citizenship and Green Politics', Journal of Business Ethics, vol. 96, pp. 299-316.

Baron, J 1981, 'Reflective Thinking as a Goal of Education', Intelligence vol. 5, pp. 291-309

Clarke, M 2003, 'Reflection: Journals and Reflective Questions a Strategy for Professional Learning', in NZARE/AARE Conference Auckland, New Zealand pp. 2-17.

Cunliffe, A 2004, 'On becoming a critically reflexive practitioner', Journal of Management Education, vol. 28 , no. 4, pp. 407-25.

Dewey, J 1933, How We Think. A restatement of the relation of reflective thinking to the educative process, D. C. Heath, Boston.

Epstein, MJ \& Roy, MJ 2001, 'Sustainability in Action: Identifying and Measuring the Key Performance Drivers', Long Range Planning, vol. 34, no. 585-604.

Epstein, MJ \& Roy, M-J 2003, 'Making the Business Case for Sustainability: Linking Social and Environmental Actions to Financial Performance', The Journal of Corporate Citizenship, no. 9, pp. 79-96.

Erek, K, Schmidt, N-H, Zarnekow, R \& Kolbe, L 2009, 'Sustainability in Information Systems: Assortment of Current Practices in IS Organizations', Americas Conference on Information Systems (AMCIS), pp. 1-9.

European Greens n.d., A Green Economic Vision for Europe Retrieved 4 Jan 2011, from http://europeangreens.eu/fileadmin/logos/pdf/policy_documents/economic/EGP_WG_ Economy_-_Paper_as_adopted_by_Ljubljana_Council.pdf

Gini, A. \& Marcoux, A. M. 2009, Case Studies in Business Ethics, $6^{\text {th }}$ edn, Pearson Prentice Hall, New Jersey.

Green, L 2008, 'Beyond the Bailout: Business Schools aim to reshape corporate morality', in Fox News Blogs ed. TF Forum. Fox News

Gilbert, T 2006, 'Mixed Methods and Mixed Methodologies-The Practical, the Technical and the political', Journal of Research in Nursing vol. 11, no. 3, pp. 205-17.

Gunn, B. \& Gullickson, B. R. 2005, 'Mind-Set', Strategic Finance, vol. 87, no. 3, p.8.

Hesse-Biber, S 2010, 'Emerging Methodologies and Methods Practices in the Field of Mixed Methods Research', Qualitative Inquiry, vol. 16, no. 6, pp. 415-8.

Hubbs, D \& Brand, C 2010, 'Learning from the Inside Out: A Method for Analyzing Reflective Journals in the College Classroom', Journal of Experiential Education vol. 33, no. 1, pp. $56-71$.

Jenkin, TA, Webster, J \& McShane, L 2010, 'An agenda for 'Green' information technology and systems research', Information and Organization, vol. In Press, Corrected Proof.

Kendall, K \& Kendall, J 2010, 'Forms of Government and Systemic Sustainability: a Positive Design Approach to the Design of Information Systems', Advances in Appreciative Inquiry, vol. 3, pp. $137-55$.

Kuhlman, T \& Farrington, J 2010, 'What is Sustainability?', Sustainability, no. 2, pp. 3436-48.

Marques, J 2009, 'Nurturing the $21^{\text {st }}$ Century Mindset: Honing Positive Tranformation', Interbeing, vol. 3, no. 2, pp. 23-9.

Newton, LH 2003, Ethics and Sustainability, Sustainable Development and the Moral Life, PrenticeHall, New Jersey.

Patenaude, G 2011, 'Climate change diffusion: While the world tips, business schools lag', Global Environmental Change, vol. 21, no. 1, pp. 259-71.

Pavolvich, K, Collins, E \& Jones, G 2009, 'Developing Students' Skills in Reflective Practice: Design and Assessment', Journal of Management Education, vol. 23, no. 1, pp. 37-58.

Reinhard, C 2005, Using Sense-Making Methodology to study the utility of Spirituality and Religion in everyday information-seeking International Communication Association New York 
Siegler, K \& Gaughan, B 2008, A Practical Approach to Green IT, Webinar. Retrieved 1 April 2011, from http://www.itmanagement.com/land/green-it-webinar/?tfso=2058

Schmidt, N-H, Erek, K, Kolbe, LM \& Zarnekow, R 2009 'Sustainable Information Systems Management', Business \&amp; Information Systems Engineering, vol. 1, no. 5, pp. 400-2.

Smith, P \& Sharicz, C 2011, 'The shift needed for Sustainability', The Learning Organization vol. 18 no. 1 , pp. $73-86$.

Titus, P \& Gremler, D 2010, 'Guiding Reflective Practice: An Auditing Framework to Assess Teaching Philosophy and Style', Journal of Marketing Education vol. 32, no. 2, pp. 182-96.

Walck, C 2009 'Integrating Sustainability Into Management Education', Journal of Management Education vol. 33, no. 3, pp. 384-90

Walker, K 1997, 'Towards Useful Theorising about Industrial Relations', British Journal of Industrial Relations vol. XV, no. 3, pp. 307-16.

Wexler, MN 2009, 'Strategic ambiguity in emergent coalitions: the triple bottom line', Corporate Communications: An International Journal vol. 14, no. 1, pp. 62-77

Weybrecht, G 2010, The Sustainable MBA-The Manager's Guide to Green Business John Wiley \& Sons England.

\section{About the Authors}

Dr. Theodora Issa

Dr. Theodora Issa is the Unit Coordinator and Lecturer at the Faculty Office, Curtin Business School, Curtin University, Australia. Theodora is responsible for the re-design of the final core unit offered at the Business School, which intends to cultivate students' learning experience, thus enhancing their abilities to participate in the development of global society, being more equipped to meet the ever-increasing challenges locally and globally. Theodora's PhD thesis on ethical mindsets, spirituality and aesthetics has been the recipient of the 2010 EFMD/Emerald Outstanding Doctoral research award. Theodora holds a Master of Business Administration, a Master of Electronic Commerce and a Master of Management Research. Theodora's engagement with higher education started with her teaching at the School of Information Systems in the areas of Web Design and Problem analysis, during which period she supervised students who implemented industry-based information systems projects. Thereafter, Theodora moved to the School of Management, teaching management and business ethics for undergraduate and postgraduate students. Theodora's research interests include teaching, online teaching and learning, ethical mindsets, ethical climate, spirituality, aesthetic judgment, sustainable business development and ethical strategies, which ignited her interest in Green IT and cloud-computing. Theodora participated in several conferences on ethics, teaching and learning, sustainability, and has been the recipient of 'best paper' awards in 2009, 2010, and 2011. Theodora has been awarded 'The New Researcher of the Year' prize by the Curtin Business School, Australia. Theodora has published in several peer-reviewed journals, is a member of editorial committees, and a member of different governing bodies. 


\section{Dr. Tomayess Issa}

Tomayess Issa is a senior Lecturer at the School of Information Systems at Curtin University, Australia. In addition, she is a Postgraduate Course leader and Postgraduate Online Coordinator. Tomayess has vast experience in Australian tertiary education, teaching Usability and Human Computer Interaction, Social Network, Sustainability and Green IT, Networking and Operating Systems. Tomayess completed her doctoral research in Web development and Human Factors. As an academic, she is also interested in establishing teaching methods and styles to enhance the students' learning experiences and resolve problems that students face. Currently, Tomayess is teaching undergraduate and postgraduate units at the School of Information Systems, focusing mainly on usability, human computer interaction, web 2.0, web 3.0, sustainability and Green IT, Cloud Computing, networking and operating system. In recognition of her hard work and dedication, she received awards from the Curtin Business School and her school for her teaching. Tomayess has participated in several conferences on Human Computer Interaction, Internet, teaching and learning, and published her work in several peer-reviewed journals. Tomayess is a member of an international conference program committee, and she is currently conduct research locally and globally in information systems, HCI, Usability, Internet, Sustainability and Green IT, social network and teaching and learning.

Assoc. Prof. Vanessa Chang

Associate Professor Vanessa Chang is currently the Dean of Teaching and Learning at Curtin Business School, Curtin University. Her research interests include Global IT Management, IT Governance, Business Process Management, Cloud Computing, and 'Green IT'. In addition, her research interests also cover areas of e-learning environments, virtual worlds, and Web 2.0. She has experience in consulting and teaching in Information Technology Management, IT Planning, Business Systems Analysis, Object-Oriented Analysis, and Agile Development Methodologies. 